\title{
Ice and the Formation of Alpine Scenery*
}

THREE dates stand out as landmarks when a 1 special revival of interest in Alpine glaciology occurred: namely, 1840, when Jean Agassiz published his "Études sur les Glaciers"; 1862, when Ramsay read his paper on the glacial origin of lakes to the Geological Society and Tyndall published his paper in the Philosophical Magazine, in which he advocated a glacial origin for the Alpine valleys; and 1900 , about which time Peach described the Alpine trough-valleys, and W. M. Davis emphasised the glacial overdeepening of the Ticino Valley, and when, a little later, Penck and Brueckner completed their monumental work on the ice age in the Alps.

It is not until the advent of the eighteenth century that we find any interest being taken in glaciers; then Scheuchzer, between 1706 and 1723, published various works on the natural history of Switzerland which contained some glacial observations, and in which he propounded the dilatation theory of glacier motion. He was followed by Gottlieb Gruner, who in 1760 published his "Eisgebirge", in which he describes the alternate advance and retreat of glaciers, illustrated by an account of the measurements of the Grindelwald Glacier between 1540 and 1750. De Saussure, between 1779 and 1796, published his famous "Voyages dans les Alpes", in which he defined the term 'glacier' and classified glaciers under three orders; in this work he also described roches moutonnées, which he attributed to water action, and he ascribed the transport of erratic blocks to a deluge or catastrophe. Though usually credited with the view that glaciers moved as solid bodies, his description of the Mount Dolent Glacier as moulding itself to the form of its valley shows that he recognised the plasticity of ice.

In the first half of the nineteenth century a new impetus was given to glacial studies by the observations of Schimper and Esmark and the writings of Venetz, Charpentier, and Agassiz, all of whom attributed the transport of the famous erraties now found on the Jura to the former greater extension of the present glaciers. This view had, however, been anticipated by Hutton.

* Substance of the presidential address by Prof. E. J. Garwood, F.R.S., before the annual gencral meeting of the Geological socicty of London on Feb. 19.
The publication of Agassiz's "Fitudes sur les Glaciers " did much to stimulate further observation on glacial phenomena during the next few years, but interest again waned after Agassiz's departure for America.

Ramsay's paper to the Geological Society in 1862 created renewed interest, fostered by Tyndall's views on the glacial erosion of Alpine valleys, and discussion was now directed to the work of ice as an erosive agent. Writers on this subject were divided into two camps. Whereas Wallace, Jukes, the brothers Geikie, Logan, Steenstrup, and Penck supported Ramsay, others, including Murchison, Lyell, the Duke of Argyll, Bonney, Rutimeyer, Heim, Credner, and Desor attributed but little erosive action to glaciers.

By the beginning of the present century most observers admitted some erosive action to ice, and more detailed observation focused attention on special features of Alpine scenery. Penck described the trough-shaped characters of Alpine valleys, and Prof. W. M. Davis attributed the hanging valleys and truncated spurs in the Val Ticino to the formation of the trough by glacial overdeepening. 'The origin of cirques was also discussed and was variously attributed to glacial erosion, water action, and frost action on the cirque wall. The work of Penck and Brueckner had established the occurrence of four glacial and three interglacial periods in the Aips, chiefly on the evidence of the deposits, and the benches which occur on the valley flanks confirm this conclusion. The truncation of the overlapping spurs which occur in the trough valleys shows, however, that the overdeepening must have been largely the result of river erosion during the last interglacial period, the valley having later been widened and modified by glacial action. Certain features, namely, the arêtes, cirque floors, the steep south side of the Alps, and in part the hanging valleys, appoar to owe their special features to the relatively protective character of ice. The steps in the main and tributary valleys present special difficulties, and cannot be satisfactorily accounted for by simple glacial erosion. They appear to be due in some way to the alternation of glacial and interglacial periods, and may possibly also be due to protection by glaciers during interglacial periods.

\section{Past and Present Whaling Records}

$\mathrm{N}$ the whaling ports which furnished the fleets of the nineteenth century lie many log-books containing records of long years of whale fishing. Charles $\mathrm{H}$. Townsend has struck upon the happy idea of using the old records (in New Bedford Public Library alone there are hundreds of log-books) to obtain information regarding the great whaling grounds, the numbers of whales slain, the position and month of capture, and so on (Bull. New York Zool. Soc., Nov.-Dec. 1931, p. 173).

There are several important collections of whaleship logs at Nantucket, Salem, and other New England ports celebrated in the history of the whaling industry, but these first records are drawn only from the New Bedford logs and refer only to the sperm whale. Nevertheless, the number of sperm whales represented by the plottings upon the chart accompanying the paper is no less than 11,026. 'The 'whaling grounds', including twelve in the North Atlantic, were visited during fairly definite seasons, as the plottings which record the position and month of each whale capture show.

In the North Atlantic the plotted areas above latitude $25^{\circ}$ show the presence of whales, with few exceptions, during the April-September period, and in the Sargasso Sea the killings are almost wholly confined to the summer period of the northern hemisphere. Between lat. $25^{\circ} \mathrm{N}$. and the equator, whales were taken chiefly during the October-March season, and along the coast of South America and towards the Cape of Good Hope the catches were largely made during the same season, or summer time in the southern hemisphere. Off Japan and along lat. $30^{\circ} \mathrm{N}$. the period changes to the April-September season. In the Pacific and to some extent also in the Atlantic Ocean, eatches for all months are recorded along the equatorial belts, and the cool Benguela and Humboldt Currents had the effect of creating all-the-year whale fisheries off the west coast of Africa and in the neighbourhood of the Galapagos Archipelago.

$$
\text { No. 3255, VoL. 129] }
$$


It must be remembered that whaling in itself was not a seasonal trade, but that the whalers made voyages lasting from two to four years, catching whales wherever they could; so that the seasonal distribution of the catches of sperm whales is the more significant. The author promises to publish further plottings of suerm whale records and of records of five other species of whales from logs still unexamined, and the results of his investigations will be looked for with rnuch interest.

Records of present-day whaling are giving rise to serious conjecture with regard to the preservation of the number of whales. The number killed during the season 1929-30, according to the Norwegian Whaling Gazette, reached the record of 38,563 individuals. Of these, 19,080 were blue whales, 14,350 finners, 1923 humpback, 922 sei, 1352 sperm, and 936 other species. Of the total number, by far the greatest proportion was taken in antarctie waters, 30,654 ; Japanese waters followed with 1714 , and the remainder were captured in tropical and northern seas. The whaler Lansing itsel had a catch of 300 whales; shore stations in Alaska and British Columbia had 675. The slaughter of whales has become a much intensified process in recent years: the Norwegian antarctic whaler Sir James Clark Ross had seven steam whale-killing boats, a crew of 245 men, and had taken during the season 1445 whales, yielding 55,000 barrels of oil, which were sold to a soap-making firm at an estimated value of one and a half million dollars.

The total world-yield of whale-oil for the season exceeded $3,427,000$ barrels, so that, through overproduction, much oil had to be stored, and as a consequence there is a slacking off in whaling during the present season. It is a relief to know that the whales will suffer less during a season, but even a years' total respite would help little towards the preservation of slow-breeding creatures like whales, in face of the capacity for slaughter of the new whaling craft.

\section{Chinese Materia Medica}

T $\mathrm{N}$ an article in NATURE of June 7, 1930, a description was given of the progress that is being made in the elucidation of the botanical origin of Chinese vegetable drugs, and it was pointed out that what might at first sight appear to be a peculiarly abstruse investigation, in which medical historians and anthropologists alone could be concerned, has resulted in a revival of interest in Ephedra and the use of its principal alkaloid, ephedrine, in the treatment of asthma.

Prof. Bernard E. Read, to whose labours this practical outcome was mainly due, is continuing these studies, and has published in recent issues of the Peking Natural History Bulletin a series of papers on Chinese drugs of animal origin, which have now been issued as a reprint. In preparing these papers, the author has had at his disposal specimens and notes of work done on Chinese materia medica at the Severance Union Medical College, Seoul, and the results of an attempt made by Miss Blanche Wu of the Department of Biology, Yenching University, to arrange the whole fauna used in Chinese medicine according to a modern scientific classification. There is, however, so much unidentified material that such a classification is still impossible.
The subject-matter is arranged in five sections: Domestic Animals; Wild Animals ; Rodents; Monkeys and Supernatural Beings; and Man as a Medicine. In each of these sections the particular animals furnishing the drugs are dealt with, and much time and trouble has clearly been expended in relating the Chinese symbols and names to their precise English equivalents. The Chinese doctor was, and probably still is, quite catholic in his taste for drugs, and the article on the pig is reminiscent of the Chicago pork factory, where everything was used but the squeak. This catholicity is not confined to the parts of an animal used, but applies equally to the species regarded as coming within the scope of practical medicine, for man himself figures prominently as a source of drugs. In this respect Chinese medicine is no worse, as Prof. Read points out, than European medicine was in the sixteenth century, and, as he pleasantly puts it, the feverish activity with which every type of animal tissue is being examined for hormones, vitamins, and other specific agents for the treatment of disease "compels an open mind that one may reach beyond the unæsthetic setting of the subject to things worth while."

\section{Forms of Communal and Industrial Waste}

1 PAPER read by J. L. Hodgson before the Royal A Society of Arts on Jan. 20, diseussing "Some Aspects of the Problem of Industrial and Communal Waste ", included a number of highly controversial questions, but dealt with many matters which are the subject of much anxious thought to-day and, above all, merit the attention of scientific workers. The contrast between the immense potential productivity of the world, which is largely the result of the application of scientific method and discoveries, and the immense amount of poverty and unemployment which exists side by side with such productive powers, is essentially a challenge to scientific workers whose labours have been a vital factor in increasing the productive capacity of the world. Among other causes of the present position indicated by $\mathrm{Mr}$. Hodgson are not only the numerous forms of industrial waste, but also those forms of communal waste such as armaments, tariffs, unemployment, inadequate housing, sanitary, medical, and educational facilities, restrictions on transport, and, sometimes, forms of rationalisation which tend to reduce the wealth and services available within a community.
These forms of communal waste are the outcome partly of ignorance and partly of vested interests, and they only persist through the absence of impartial scientific inquiry and analysis on a scale competent and authoritative enough to compel rational action.

Among the factors responsible for the present situation, the concentration of credit power in the hands of socially irresponsible people is regarded as fundamental, and in its reaction on industry has encouraged continued increase of technical efficiency, the reduction of wages and staff, replacement of skilled by unskilled labour, mass-unemployment, the formation of mergers or trusts, the growth of tariffs, leading ultimately to restricted output and sabotage of excess products.

Mr. Hodgson, pointing out the absurdity of production which leads only to waste, suggested that strenuous efficiencies are surplus, and that if communal wastes are eliminated and routine work efficiently organised and shared by all, a comparatively small amount of routine will be required of each individual worker. Our aim should be to organise the produc. tion of the goods necessary for the maintenance and 